\title{
Laryngocoele formation after ingestion of fish bone
}

\author{
Shanna Leonard, ${ }^{1}$ Andrew Kelly, ${ }^{2}$ Brendan Hanna ${ }^{3}$
}

${ }^{1}$ General Surgery, Belfast Health and Social Care Trust, Belfast, UK

${ }^{2}$ ENT, Antrim Area Hospital, Antrim, UK

${ }^{3}$ ENT, Royal Victoria Hospital, Belfast, UK

\section{Correspondence to} Dr Shanna Leonard, sleonard09@qub.ac.uk

Accepted 5 May 2017
CrossMark

To cite: Leonard S, Kelly A, Hanna B. BMJ Case Rep Published Online First: [please include Day Month Year]. doi:10.1136/bcr-2016217994

\section{DESCRIPTION}

A 72-year-old man presented to the clinic with a 3-week history of anterior left neck pain. $\mathrm{He}$ described constant discomfort since eating fish a few weeks prior. He recalled pain at the time of eating, and felt he had ingested a fish bone.

There was no dysphagia, dyspnoea or haemoptysis on presentation. He had a medical history of type II diabetes mellitus, with no previous Ear, Nose and Throat issues.

Examination of the neck and oropharynx was normal. There were no palpable nodes or masses. Flexible nasendoscopy demonstrated a normal larynx. A lateral X-ray of the neck was arranged and showed no foreign body.

He was treated with simple analgesia and antacid, with a plan to review in 1 week.

$\mathrm{He}$ was reviewed and again examination and nasendoscopy were normal. CT scan revealed a traumatic laryngocoele at the left piriform sinus (figures 1 and 2).

Laryngocoeles are often formed by increased intraglottic pressure and can become symptomatic as a result of a neoplastic process. Cases to date suggest that prolonged or repeated raised intraglottic pressure is enough to cause laryngocoele, and an insult such as trauma may cause it to present itself, or indeed increase to become symptomatic. ${ }^{12}$

This particular patient had no evidence of laryngeal disease on both imaging and endoscopy.

A possible complication of a large laryngocoele would include airway obstruction or dysphonia. Management of these is more complex than in this case. Treatment includes an open surgical approach or, in more recent times, $\mathrm{CO}_{2}$ laser resection.

Our patient was well, with no airway issues, and was easily managed with simple analgesia at home.

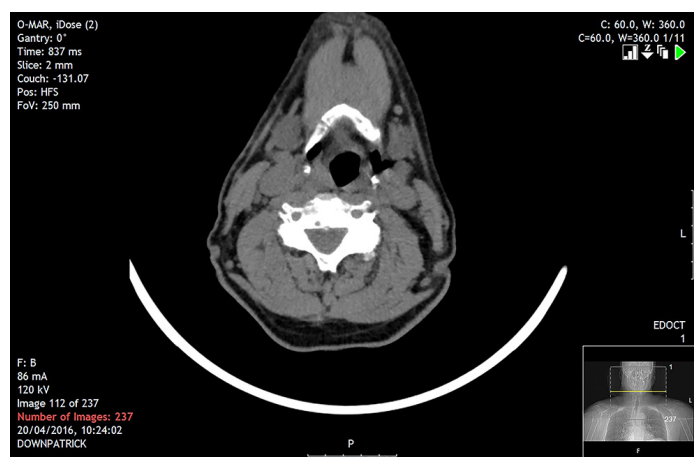

Figure 1 CT revealing left-sided laryngocoele.

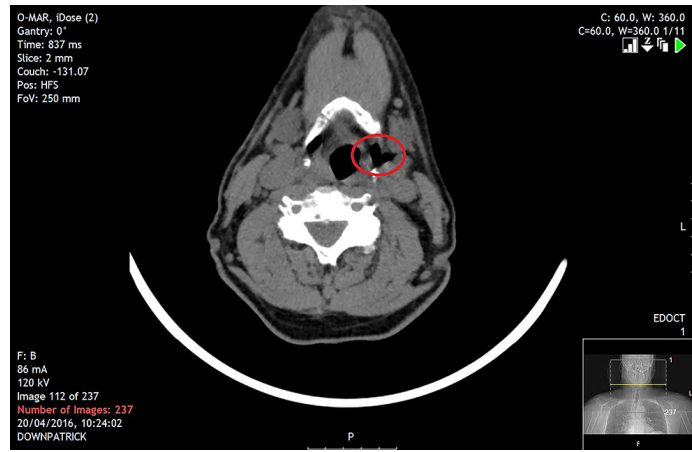

Figure 2 Laryngocoele highlighted.

Learning points

- Laryngocoeles are dilatations within the larynx.

- Often, laryngocoeles are asymptomatic but can cause cough, pain, stridor and hoarseness. ${ }^{1}$

- Laryngocoeles may be caused by increased intraglottic pressure, such as singing, trumpet playing or occasionally malignancy. ${ }^{2}$

- Formation following trauma is very rare, and trauma may simply cause a pre-existing state to become symptomatic.

- Treatment may be conservative, surgical or laser resection, depending on each patient and their symptoms.

Contributors SL and AK contributed to the original manuscript and were both involved in writing the manuscript and including images. $\mathrm{BH}$ is the supervising consultant.

Competing interests None declared.

Patient consent Obtained.

Provenance and peer review Not commissioned; externally peer reviewed.

(c) BMJ Publishing Group Ltd (unless otherwise stated in the text of the article) 2017. All rights reserved. No commercial use is permitted unless otherwise expressly granted.

\section{REFERENCES}

1 Lancella A, Abbate G, Dosdegani R. Mixed laryngocele: a case report and review of the literature. Acta Otorhinolaryngol Ital 2007;27:255-7

2 Prasad KC, Vijayalakshmi S, Prasad SC. Laryngoceles presentations and management. Indian J Otolaryngol Head Neck Surg 2008;60:303-8

3 Upile T, Jerjes W, Sipaul F, et al. Laryngocele: a rare complication of surgical tracheostomy. BMC Surg 2006;6:14. 
Copyright 2017 BMJ Publishing Group. All rights reserved. For permission to reuse any of this content visit http://group.bmj.com/group/rights-licensing/permissions.

BMJ Case Report Fellows may re-use this article for personal use and teaching without any further permission.

Become a Fellow of BMJ Case Reports today and you can:

- Submit as many cases as you like

- Enjoy fast sympathetic peer review and rapid publication of accepted articles

Access all the published articles

- Re-use any of the published material for personal use and teaching without further permission

For information on Institutional Fellowships contact consortiasales@bmjgroup.com

Visit casereports.bmj.com for more articles like this and to become a Fellow 